\title{
Macro-Microscopic evaluation, Physicochemical analysis and HPTLC Finger printing of Curculigo orchioides Gaertn. Rhizome
}

\author{
Deepa Yadav ${ }^{1}$, Mohd Salim Reshi ${ }^{1}$, Sadhana Shrivastava ${ }^{1}$, Nalini Srivastava ${ }^{2}$, Sunil Kumar Koppala Narayana ${ }^{3}$, Sangeeta Shukla ${ }^{1 *}$ \\ 'UNESCO-Trace Element Satellite Center, School of Studies in Zoology, Jiwaji University, Gwalior, Madhya Pradesh, INDIA. \\ ${ }^{2}$ School of Studies in Biochemistry, Jiwaji University, Gwalior, Madhya Pradesh, INDIA. \\ SSDM Center of Research in Ayurveda and Allied Sciences, Laxminarayana Nagar, Kuthpady, Udupi, Karnataka, INDIA.
}

\begin{abstract}
Introduction: Curculigo orchioides Gaertn. Family Hypoxydaceae (Amaryllidaceae) is a perennial herb with finger like rhizome. Its rhizomes have been significantly used in treatment of various ailments including cancer. Methods: Macro-microscopic analyses, physico-chemical studies and HPTLC finger printing of rhizomes of $C$. orchioides were performed according to pharmacopoeial procedures. Results: Microscopic analysis has shown rows of rectangular and conical cells in cork, thin walled cortex, parenchymatous cells, starch grains, crystal of calcium oxalate, mucilage cell and spiral xylem vessel in the rhizomes of $C$. orchioides. Physicochemical studies revealed loss on drying $(10.469 \%)$, total ash $(8.463 \%)$, acid insoluble ash $(1.10 \%)$, water-soluble ash $(2.163 \%)$, alcohol soluble extractive value $(3.036 \%)$, and water-soluble extractive value $(22.666 \%)$ of the raw drug. Ethanol extract of the plant were fingerprinted in petroleum ether and ethyl acetate (7.0:3.0) solvent system and scanned densitometrically after
\end{abstract}

dipping in anisaldehyde-sulphuric acid reagent followed by heating at $105^{\circ} \mathrm{C}$. Conclusion: These specific identities will be useful in identification and authentication of the raw drug in dried form.

Key words: Curculigo orchioides, HPTLC fingerprinting, Pharmacognostic, Standaridisation, Quality control.

Corresponding author: Sangeeta Shukla, UNESCO-Trace Element Satellite Center, School of Studies in Zoology, Jiwaji University, Gwalior, Madhya Pradesh, INDIA.

Phone no: 91-751-2442750

Email: profsshukla@gmail.com DOI : $10.5530 /$ pj.2016.5.3

\section{INTRODUCTION}

Curculigo orchioides Gaertn., syn. C. malabarica Wight., C. brevifolia Dryand. ${ }^{1}$ and Hypoxis orchioides Kurz. ${ }^{2}$ is well known medicinal plant known as Kalimusli in Hindi. It is a perennial herb with a rosette of sensible with linear lanceolate, membraneous leaves and bright yellow colour flowers, closed to ground. ${ }^{2}$ The plant is native to India ${ }^{3}$ and distributed from sub-tropical Himalayas, West Bengal, Assam, Konkan, West peninsula to Kanyakumari. ${ }^{2}$ Its rhizomes are widely used as a demulcent, diuretic and aromatic tonic, aphrodisiac, in the treatment of leprosy and nervous disease. ${ }^{4}$ Rhizomes of $C$. orchioides have been reported for their medicinal properties like platelet regeneration, ${ }^{5}$ antioxidant activity, ${ }^{6}$ hepato-protective efficacy, ${ }^{7}$ antipyretic activity ${ }^{8}$ and immune stimulant properties. ${ }^{9}$

Vedic manuscripts described the therapeutic potential of $C$. orchioides and are well documented in the treatise of Ayurveda in the name of Talamuli. Accordingly, the synonyms and medicinal properties of $C$. orchioides are depicted in Sanskrit shlokas mentioned in Bhavprakash Nighantu (Shloka 183). ${ }^{10}$

Rhizomes of this plants has been described to possess medicinal properties as sweet, cooling, diuretic, aphrodisiac, anti-aging and considered as a Rasayana drug which can be used in male infertility, hemorrhoids, piles, which also increases Kapha and reduces Pitta daha (burning sensation), acts as stimulant and gives strength.

C. orchioides has been reported with constituents ${ }^{11}$ such as flavones, glycosides, steroids (sitosterol, stigmasterol and yuccagenin), ${ }^{12}$ terpenoids, saponins, glucose, mannose, xylose, glucoronic acid, resin, tannin, fat, mucilaginous substances ${ }^{13}$ and other secondary metabolites. Steam distilled fraction of C. orchioides has reported for its antibacterial activity against Gram-negative and Gram-positive pathogens. ${ }^{14}$ Methanolic extract of rhizomes of $C$. orchioides is reported for its immunostimulatory action against cyclophosphamide induced toxicity and neuroprotective efficacy against cyclophosphamide neurotoxicity. ${ }^{15-16}$ Various studies have been reported for its antidiabetic activity; ethanolic extract and aqueous extract of C. orchioides in alloxan induced diabetes. ${ }^{17-18}$

With this background detailed quality control studies were undertaken for this traditional raw drug with the aim of developing standards of authenticity.

\section{MATERIALS AND METHODS}

\section{Collection and Identification}

Dried rhizomes were collected from local Ayurveda pharmacy in Gwalior, Madhya Pradesh. The plant material was authenticated at Pharmacognosy department of SDM Center for Research in Ayurveda and Allied Sciences, Udupi, Kuthpady, Karnataka and (a specimen (725/16021205) is being maintained for future reference. The dried rhizomes were cleaned, coarsely powder and used for macroscopic and microscopical characterization, phytochemical analysis and HPTLC.

\section{Macro-microscopic analysis}

Macroscopic characters of fresh rhizome and powder were keenly observed under naked eyes to record the specific botanical characters. The external features of the test samples were documented using Canon IXUS digital camera.

Rhizomes were preserved in formalin-acetic acid-alcohol preservative solution $\{5 \%$ formalin $(5 \mathrm{ml}), 5 \%$ acetic acid $(5 \mathrm{ml})$ and $50 \%$ ethyl alcohol $(90 \mathrm{ml})\}$, before 48 hours ${ }^{19}$ of microscopic analysis. Very thin transverse sections of rhizome were obtained using sharp blade followed by safranine staining. ${ }^{20}$ Transverse sections were photographed using Zeiss AXIO trinocular microscope attached with Zeiss AxioCam camera under bright field light. Magnifications of figures are indicated in scale bars. For powder microscopy, $1 \mathrm{~g}$ of coarse powder was sift through 80 pore size mesh. A pinch of powder was mixed with drops of choral hydrate on 
microscopic slides and mounted with a drop of glycerine-water. Slides were observed and characterized under Zeiss AXIO trinocular microscope. Magnifications are indicated by scale bars. ${ }^{21}$

Physico-chemical analysis: Physico-chemical characterization like loss on drying at $105^{\circ} \mathrm{C}$, total ash, acid insoluble ash, water soluble ash, ethanol and water soluble extractives values were determined as per Quality Standard of Indian Medicinal Plants. ${ }^{22}$

\section{HPTLC Fingerprinting}

One gram of powdered rhizomes were extracted with $10 \mathrm{ml}$ ethanol and kept for cold percolation for $24 \mathrm{~h}$ and filtered. 4, 8 and $12 \mu \mathrm{l}$ of the plant extract were applied on a pre-coated silica gel F254 on aluminium plates to a band width of $7 \mathrm{~mm}$ using Linomat 5 TLC applicator. C. orchioides plate was developed in Petroleum ether: Ethyl acetate $(7.0: 3.0 \mathrm{v} / \mathrm{v})$. The developed plate was visualized in UV $254 \mathrm{~nm}, 366 \mathrm{~nm}$ and then derivatised with anisaldehyde sulphuric acid reagent ${ }^{23}$ and scanned under UV $254 \mathrm{~nm}, 366 \mathrm{~nm}$ and $620 \mathrm{~nm}$ post derivatisation. $R_{\mathrm{p}}$ colour of the spots and densitometric scan were recorded using CAMAG Scanner 4..$^{24-25}$

\section{RESULTS}

Macro-microscopic observations: Macroscopic studies showed blackish brown rhizomes about 10 to $15 \mathrm{~cm}$ long, cylindrical and straight to slightly curve. Transversely cut pieces are yellowish brown externally and yellowish off-white internally. External surface was prominent with wrinkled, transverse cracks with a few root scars, nodes and internodes (Figure 1a-c). Microscopic characters of transverse section of Curculigo orchioides with narrow strip of cork consisting of 5 to 7 rows of conical and rectangular cells, thin walled cortex consists of parenchymatous cells, densely filled starch grains and acicular crystal of calcium oxalate and vascular bundle lying underneath the endodermis (Figure 1d-1f) . Powder microscopy of coarse powder of rhizomes of Curculigo orchioides was dark brown, slightly bitter in taste. Powder microscopy depicts the cork in transverse and surface view (Figure 2a-c). Powder contains annular crystal of calcium oxalate, mucilage cell and spiral xylem vessel. Power microscopy also shows spiral fragments of lignified vessels of vascular bundles (Figure 2d-2l).

Physico-chemical analysis: Physico-chemical characters were performed as per Quality Standard of Indian Medicinal Plants ${ }^{22}$ (Table 1).

HPTLC Finger printing: $\mathrm{R}_{\mathrm{f}}$ values and colour of the spots in chromatogram developed in petroleum ether:ethyl acetate (7.0:3.0) for ethanolic extract of rhizomes were recorded (Table 2). TLC photo-documentation revealed presence of many phytoconstituents with different $R_{f}$ values and HPTLC densitometric scan of the plates showed numerous bands under short UV, long UV and $620 \mathrm{~nm}$ (after derivatisation). On photo documentation no spots under short UV, 4 spots under long UV and 3 spots under $620 \mathrm{~nm}$ post-derivatisation with anisaldehyde sulphuric acid spray reagent (Figure 3a-c). Densitometric scan at $254 \mathrm{~nm}$ revealed 5 peaks corresponding to 5 different compounds in the ethanolic extract, compounds with $\mathrm{R}_{\mathrm{f}}-0.03$ (71.37\%), 0.19 (2.77\%), 0.38 (18.47\%), 0.76 (2.91\%) and $0.88(4.47 \%)$ in Figure 4a. Densitometric scan at $366 \mathrm{~nm}$, (Figure $4 \mathrm{~b})$ showed 8 peaks, peak with $\mathrm{R}_{\mathrm{f}}-0.07$ (9.04\%), $0.11(14.03 \%)$, 0.17 (10.40\%), 0.22 (50.45\%), 0.75 (5.94\%), 0.86 (5.30\%), 0.90 (3.38\%) and $0.98(0.45 \%)$. Figure $4 \mathrm{c}$ depicts 8 peaks- with $\mathrm{R}_{\mathrm{f}}-0.03(42.03 \%)$, 0.32 (3.89\%), 0.37 (6.48\%), 0.41 (5.57\%), 0.58 (9.36\%), 0.65 (11.79\%), $0.85(10.69 \%)$ and $0.86(10.18 \%)$ (Table 3$)$.

\section{DISCUSSION}

C. orchioides rhizomes are mucilaginous in nature and well known Rasayana drug in Ayurveda System of Medicine. Morphological and anatomical standardization of herbal drugs needs the information from basic disciplines of plant sciences for identification of plant drug. Simultaneously for identification of chemical nature of plant in term of physicochemical analysis, qualitative and quantitative analysis for the detection of active constituent expertise are required. According to Kunle et al, ${ }^{26}$ standardization of herbal drug is a series of protocols which assure the quality, efficiency and safety of plant drug. Macro-microscopy helps in the identification of plant characters anatomically and helps in identification of botanical background. Present study shows a clear zone of rectangular and tangentially elongated cork cells. Thin walled oval and spherical parenchymatous cells with small intercellular spaces were recorded. Parenchymatous cells were distributed throughout the section while some parenchymatous cells show the presence of bundles and needle like crystals of calcium oxalate. These observations are in support of the previous studies on pharmacognostic evaluation of Curculigo orchioides. ${ }^{27-29}$

Standardization and authentication of plants was done by evaluating physicochemical testing. ${ }^{30-32}$ The values obtained in the study will serve as constants for quality standard measures for standardization of drug in the dried form.

High performance thin layer chromatography (HPTLC) serves as quality assessment tool which helps in identification of variation in chemical composition plants.TLC identity is a part of every herbal monograph of international standards. ${ }^{33}$ HPTLC fingerprinting shows different $R_{f}$ values at different wavelength and reported values can be used as quality indicating fingerprint for Curculigo orchioides in the dried form.

Findings reported in the present investigation are in support of $\mathrm{API}^{34}$ and QSIMP $2012^{2}$.

\section{CONCLUSION}

Pharmacognostical characterization of the C. orchioides has been done as per pharmacopoeial methodology. Present study explores the botanical (in terms of macro-microscopic observations), physicochemical observation (in terms of total ash, AIA, WSA, ASE, WSE and loss on drying)

Table 1: All the experiments were performed in triplicates. Values are expressed in $\pm \mathrm{SE}=3$

\begin{tabular}{cc}
\hline Parameter $(\%$ w/w) & Mean value \pm SE $(\mathrm{N}=3)$ \\
\hline Loss on drying & $10.469 \pm 0.002$ \\
Total Ash & $8.463 \pm 0.015$ \\
Acid Insoluble Ash & $1.10 \pm 0.005$ \\
Water soluble Ash & $2.163 \pm 0.086$ \\
Alcohol soluble extractive value & $3.036 \pm 0.056$ \\
Water soluble extractive value & $22.666 \pm 0.088$ \\
\hline
\end{tabular}

Table 2: $\mathbf{R}_{\mathrm{f}}$ values of all the samples

\begin{tabular}{ccc}
\hline At 254 nm & At 366 nm & $\begin{array}{c}\text { After post } \\
\text { derivatisation }\end{array}$ \\
\hline- & 0.16 (FL. blue) & - \\
- & - & 0.51 (L. purple) \\
- & - & 0.56 (L. purple) \\
- & 0.63 (FL. blue) & - \\
- & $0.71($ F aqua blue) & - \\
- & - & 0.74 (L. purple) \\
\hline
\end{tabular}

${ }^{\star}$ L-Light, D-Dark, F-Fluorescence. 
Yadav et al:: Microscopy, physico-chemical analysis and HPTLC fingerprinting of Curculigo orchioides Gaertn.

Table 3: Densiometric scan of ethanolic extract of Curculigo orchioides

\begin{tabular}{|c|c|c|c|c|c|}
\hline \multicolumn{2}{|c|}{$254 \mathrm{~nm}$} & \multicolumn{2}{|c|}{$366 \mathrm{~nm}$} & \multicolumn{2}{|c|}{$620 \mathrm{~nm}$} \\
\hline$R_{f}$ & $\%$ Area & $R_{f}$ & $\%$ Area & $R_{f}$ & $\%$ Area \\
\hline 0.03 & 71.37 & - & - & 0.03 & 42.03 \\
\hline- & - & 0.07 & 9.04 & - & - \\
\hline- & - & 0.11 & 14.03 & - & - \\
\hline- & - & 0.17 & 10.40 & - & - \\
\hline 0.19 & 2.77 & - & - & - & - \\
\hline- & - & 0.22 & 50.45 & - & - \\
\hline- & - & - & - & 0.32 & 3.89 \\
\hline 0.38 & 18.47 & - & - & 0.37 & 6.48 \\
\hline- & - & - & - & 0.41 & 5.57 \\
\hline- & - & - & - & 0.58 & 9.36 \\
\hline- & - & - & - & 0.65 & 11.79 \\
\hline 0.76 & 2.91 & 0.75 & 5.94 & - & - \\
\hline- & - & - & - & 0.85 & 10.69 \\
\hline- & - & 0.86 & 5.30 & 0.86 & 10.18 \\
\hline 0.88 & 4.47 & - & - & - & - \\
\hline- & - & - & - & - & - \\
\hline- & - & 0.90 & 3.38 & - & - \\
\hline- & - & 0.98 & 0.45 & - & - \\
\hline
\end{tabular}

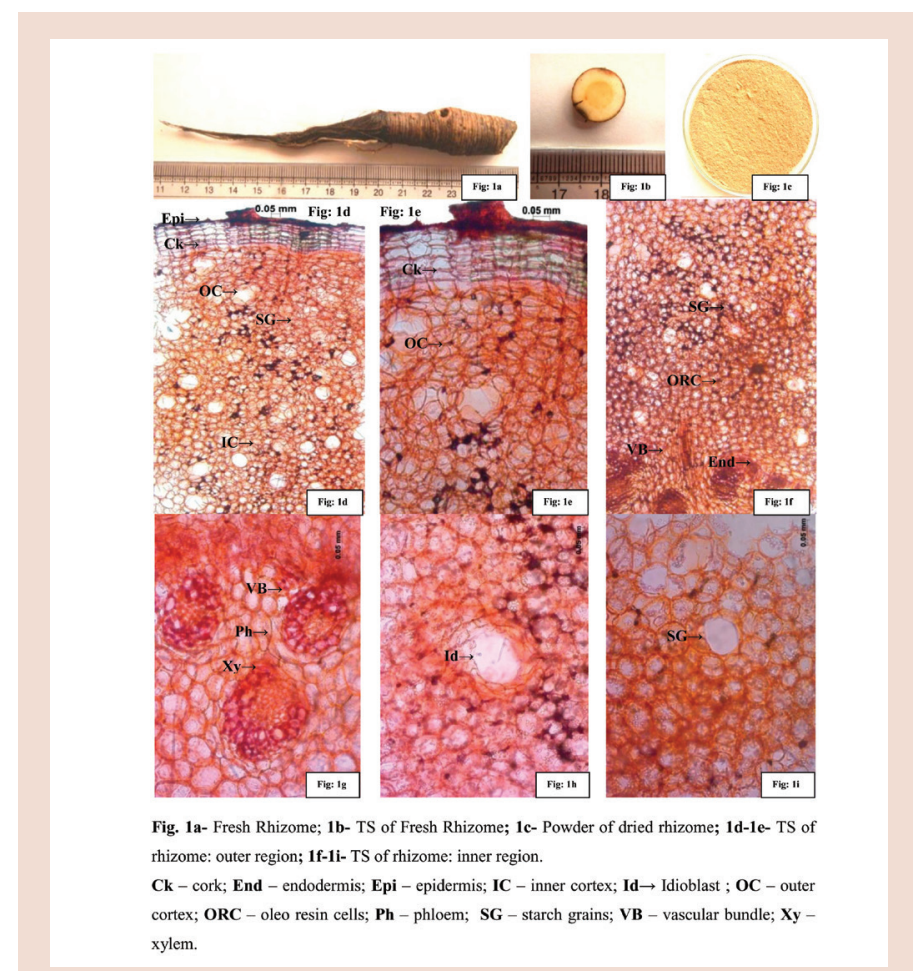

Figure 1: Macro-microscopic features of rhizome of Curculigo orchioides.

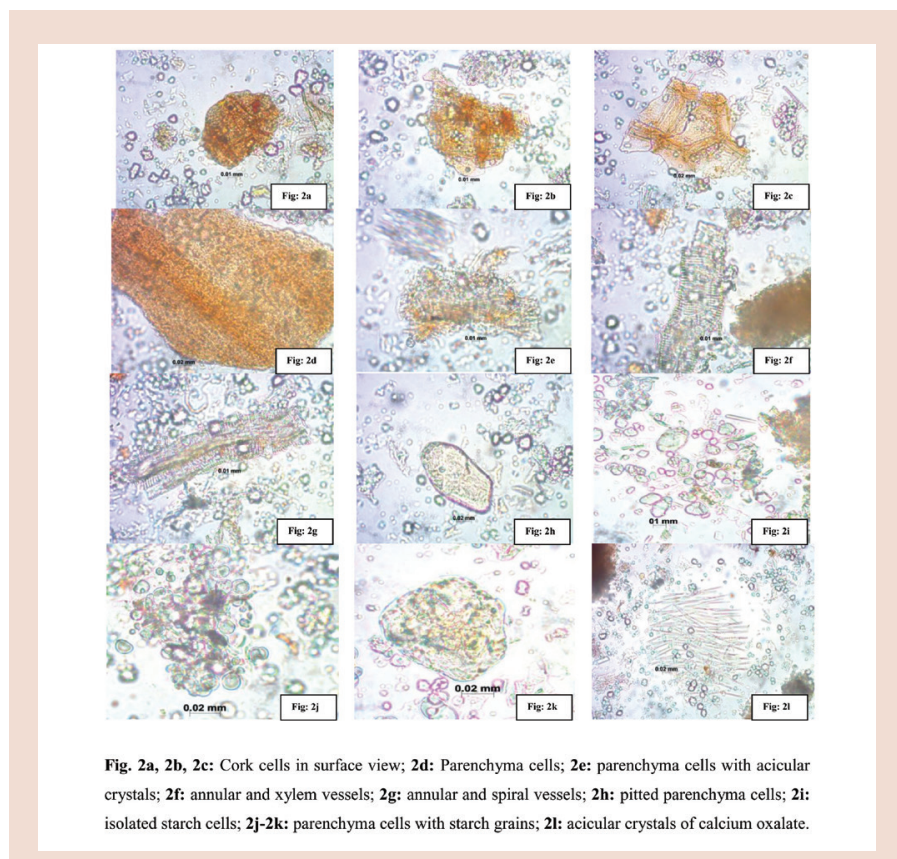

Figure 2: Powder microscopy of rhizome of Curculigo orchioides. 


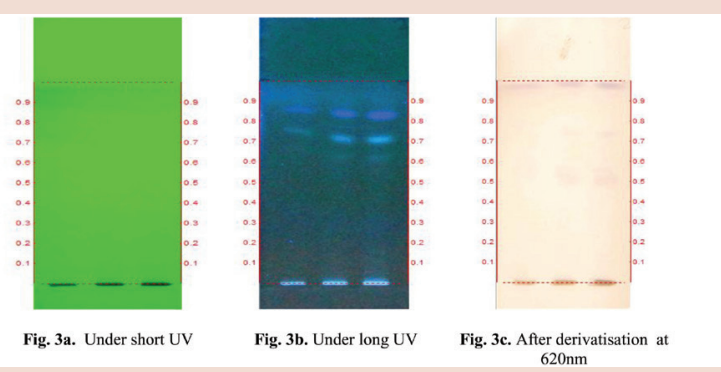

Figure 3: TLC Photodocumentation of ethanolic extract of rhizome and Curculigo orchioides.

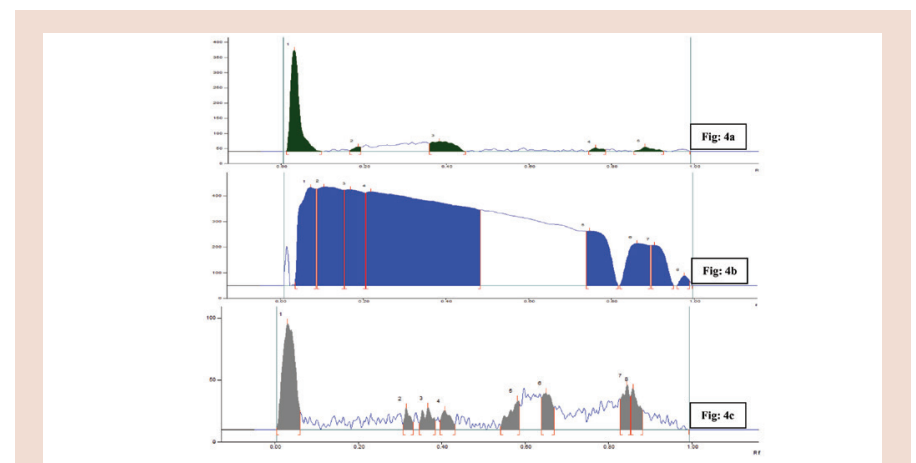

Fig. 4a. At $254 \mathrm{~nm}$; 4b. At $366 \mathrm{~nm} ; 4$ c. At $620 \mathrm{~nm}$ after derivatisation.

Figure 4: HPTLC Densitometric scan of ethanolic extract of rhizome of Curculigo orchioides.

identification and authentication of drug in dried form.

\section{ACKNOWLEDGEMENT}

Authors are highly grateful to Jiwaji University, Gwalior, Madhya Pradesh for financial assistance (Dev/2016/214) dated 31/05/2016. Authors highly regard Dr. B. Ravishankar, Director, SDM Centre for Research in Ayurveda for providing the lab facilities. Suchitra N Prabhu is gratefully acknowledged for constant support during the study.

\section{CONFLICT OF INTEREST}

The author declare no conflict of interest.

\section{ABBREVIATIONS USED}

TLC: Thin Layer Chromatography; HPTLC: High Performance Thin Layer Chromatography; QSIMP: Quality Standard of Indian Medicinal Plant; AIA: Acid Insoluble Ash; WSA: Water Soluble Ash; ASE: Alcohol Soluble Extractive; WSE: Water Soluble Extractive.

\section{REFERENCES}

1. Asif A. Review on phytochemical and ethnopharmacological activities of Curculigo orchioides. Mahidol Univ J Pharm Sci. 2012; 39(3-4)1-10.

2. Quality standard of Indian Medicinal Plant, Indian Council of Medical Research, New Delhi; 2012. Vol (10).

3. Asif M, Kumar A. Acute toxicity study and in-vivo anti-inflammatory activity of different fractions of Curculigo orchioides Gaertn. rhizome in albino wistar rats. Iran J Pharm Sci. 2010;6(3):191-8.
4. Nadkarni KM, Nadkarni AK, Chopra RN. Indian Materia Medica. $3^{\text {rd }}$ ed. Popular Prakasan, Bombay; 1976.

5. Suri SS, Jain S, Ramawat KG. Platelet regeneration and bulbil formation in vitro from leaf and stem explants of Curculigo orchioides, an endangered medicinal plant. Scientia Horticulturae. 1999;79(1):127-34.

6. Venukumar MR, Latha MS. Antioxidant activity of Curculigo orchioides in Carbon tetrachloride induced hepatopathy in rats. Indian J Clin Biochem. 2002;17(2):80-7.

7. Venukumar MR, Latha MS. Hepatoprotective effect of the methanolic extract of Curculigo orchioides in CCl4 -treated male rats. Indian J Pharmacol 2002; 34:269-75.

8. Pandit P, Balaraju P, Ravikanth V, Swetha M, Shireesha M, Reddy KN. Evaluation of anti-pyretic and analgesic activity of Curculigo orchioides Gaertn rhizomes. Int J Pharm Sci. 2011;2(5-6):5-6.

9. Lakshmi V, Pandey K, Anju Puri, Saxena RP, Saxena KC, Immunostimulant principles from Curculigo orchioides, J Ethnopharmacol. 2003; 89 (2):181-4

10. Chunekar KC. Bhava Prakash Nighantu. $10^{\text {th }}$ ed. Varanasi; Chaukhambha Bharati Academy. 1995; Shloka 183. p

11. Susindran $P$, Ramesh N. Phytochemical screening and antimicrobial activity of Curculigo orchioides Gaertn rhizome, an endangered medicinal herb. International Journal of current Research. 2014;6(10):9104-7.

12. Rao PKV, Ali AN, Reddy MN. Occurence of both saponins and alkaloids from Iycorine in Curculigo orchioides. Indian J of Pharma Sci. 1978;40:104-5.

13. Nema RK, Ramawat KG. Isolation and identification of a new molecule from Curculigo orchioides (Hypoxidaceae). International Journal of Pharmacognosy and Phytochemical Research. 2012;1(2):24-8.

14. Nagesh KS, Shanthamma C. Antibacterial activity of Curculigo orchioides rhizome extract on pathogen bacteria. Afr J Microbiol Res. 200;391(3):5-9.

15. Mehta J, Nama KS. A review on ethanomedicines of Curculigo orchioides Gaertn (Kali Musli): Black Gold. Int J Phar \& Biomedi Res. 2014;1(1):12-6.

16. Ramchandani D, Ganeshpurkar A, Bansal D, Karchuli MS, Dubey. Protective effect of Curculigo orchioides on cyclophosphamide induced neurotoxicity in murine model. Toxicol Itn. 2014;21(3):232-5.

17. Chauhan NS, DixitVK. Antihyperglycemic activity of ethanolic extract of Curculigo orchioides Gaertn. Pharamcognosy Magzine. 2007;3(12):237.

18. Madjhvan V, Joshi R, Murali A, Yoginarasimhan SN. Antidiabetic activity of Curculigo orchioides root tuber. Pharmaceutical Biol. 2007;45(1):18-21.

19. Sass JE. Elements of botanical micro technique. McGraw Hill book Co., New York 1940.

20. O'Brein TP Feder N, Mc Cull ME. Polychromatic staining of plant cell walls by toluidine blue-O. Protoplasma 1964;59(2):368-73.

21. Fahn A. Plant Anatomy. $3^{\text {rd }}$ ed. Pergaman Press, New York. 1987; p554.

22. Quality standard of Indian Medicinal Plant, Indian Council of Medical Research, New Delhi; 2014.

23. Waksmundzka HM, Sherma J, Kowalska T. Thin layer chromatography in phytochemistry, London: CRC Press, Taylor \& Francis Group: p 595.

24. Stahl I. Thin layer chromatography. A Laboratory Hand Book (student edition), Berlin, Springer-Verlag 1969; 52-86.

25. Sethi PD. High Performance Thin Layer Chromatography. 1st ed. New Delhi, CBS Publishers and Distributors; 1996.

26. Kunle OF, Egharevba HO, Ahmadu PO. Standardization of herbal medicines: a review. Int J Biodivers Conserv 2012;(4):101-12.

27. Patil AG, Koli SP, Patil DA, Phatak AV, Chandra N. Pharmacognostic evaluation and HPTLC fingerprint profile of Curculigo orchioides Gaertn. Rhizomes. Int J Pharm Bio Sci 2012;3(3):101-11.

28. Theng KB, Korpenwar AN. Preliminary phytochemical and physicochemical analysis of Curculigo orchioides Gaertn. Root tubers. Int J Bioassays 2014; 3(10):3373-5.

29. Agrahari AK, Panda SK, Meher A, Padhan AR Khaliquzzama M. Phytochemical Screening of Curculigo orchioides Gaertn. Root tubers. J Chem Pharm Res. 2010;2(2):107-11.

30. Anonymous. Quality Control Methods for Medicinal Plants Materials. World Health Organization. Geneva. 1992.

31. Anonymous. Quality Assurance of Pharmaceutical. A compendium of guidelines and related materials, A good manufacture practices and inspection. World Health Organization. Geneva. 1996a; $\mathrm{p}-2$.

32. Anonymous. Guidelines for the Assessment of Herbal Medicines. In: WHO Technical support series. World Health Organization. Geneva. 1996b;p-863.

33. Sunil Kumar KN, Ravishankar B, Yashovarma B, Rajakrinshnan R, Thomas J. Development of quality standards of medicinal mistletoe-Helicanthes elastica (Desr.) Danser employing Pharmacopoeial procedures. Saudi Journal of Biological Sciences. (2016), http://dx.doi.org/10.1016/j.sjbs.2016.02.023 


\section{PICTORIAL ABSTRACT}

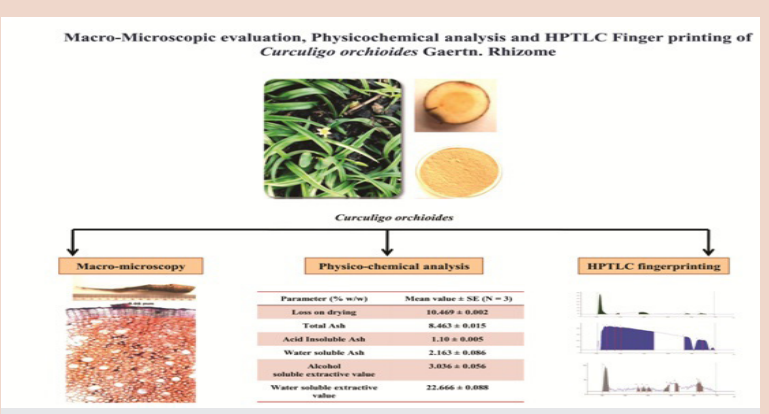

- Microscopy of Curculigo orchioides Gaertn. showed the presence of rectangular and conical cells in cork, thin walled cortex, parenchymatous cells, starch grains, crystal of calcium oxalate, mucilage cell and spiral xylem vessel.

- Ethanolic extract of dried rhizomes of Curculigo orchioides Gaertn. revealed physico-chemical constants as LOD (10.469\%), TA (8.463\%), AIA (1.10\%), WSA (2.163\%), ASE (3.036\%) and WSE (22.666\%).

- HPTLC fingerprint profile was obtained at different wavelengths with different Rf peaks.

- Microscopy, physico-chemical constants and HPTLC fingerprint profile will be useful for identification and authentication of dried rhizomes of Curculigo orchioides Gaertn.
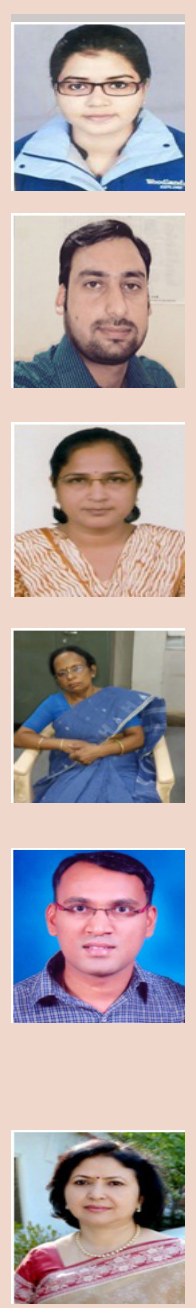

\section{ABOUT AUTHORS}

Ms Deepa Yadav: Is pursuing Ph.D. from School of Studies in Zoology, Jiwaji University, Gwalior, Madhya Pradesh. She was awarded JRF of MPCST, Bhopal, Madhya Pradesh. She has been awarded for best paper presentation by UGC-CRO Bhopal. She has published a book entitled "Studies on T cell signaling mechanisms". Her areas of research interest Molecular- Immunology, Pharmacology, Toxicology, and Cancer Prevention.

Mohd Salim Reshi: Is pursuing Ph.D. in School of Studies in Zoology, Jiwaji University, Gwalior. He was awarded JRF and SRF of UGC, New Delhi. He has been awarded MPCST Young Scientist award and many other awards in several conferences and symposia. He is working with Nanoparticles in Hepatoprotection and Cancer Prevention. His areas of research interest are Pharmacology, Toxicology, Hepatoprotection and Cancer Prevention.

Dr. Sadhana Shrivastava: Is working as Post Doctoral Fellow in School of Studies in Zoology, Jiwaji University, Gwalior. She has been awarded various Fellowships from UGC, ICMR and DST, New Delhi. She is author of 40 research papers in field of Pharmacology and Toxicology.

Dr. Nalini Srivastava: Is B.Sc., M.Sc., Ph.D., from Kanpur University, Uttar Pradesh, India. She was awarded JRF from CSIR New Delhi. She has completed many projects from agencies like UGC, DST and MPCST. She has published 50 research papers in journal of National and International repute.

Dr KN Sunil Kumar B.Sc., M.Sc. and PhD: In Pharmacognosy is working as Senior Research Officer in Pharmacognosy and Phytochemistry at SDM Ayurveda and Allied Sciences, Udupi, India 574118. He obtained Senior Research Fellowship from ICMR, Young Scientist Award, VGST, Govt. Of Karnataka and Dr. PD Sethi award for 5 best HPTLC papers. He is investigating projects on standardization of Ayurvedic formulation from agencie like UGC, VGST, RGUHS and PCIM (AYUSH). He is Author of 64 research papers and 55 monographs on pharmacognosy, phytochemistry and standardization of medical plants/products. He is also serving as Chief editor Journal of Ayurvedic and Herbal medicine, Associate editor The journal of Phytopharmacology, Executive editor Research and review: Pharmacognosy and Phytochemistry, Editorial advisory board member of Journal of Tradition Medicinal and Clinical Naturopathy and subject editor Pharmacognosy Ayu-An international Quarterly Journal of Research in Ayurveda. He is a member of Board of tudies, Department of Botany, SDM College (Autonomous) Ujire. He is a life member of Society of Pharmacognosy.

Dr. Sangeeta Shukla, D.Sc., Ph. D., M.Sc. (Gold Medal in Life Sciences): Is Vice Chamcellor of Jiwaji University, Gwalior (M.P.) She was awarded JRF of ICMR, SRF of CSIR, RA of UGC, New Delhi. She has been awarded ISCA and MPCST Young Scientist award. She has completed many projects from agencies like UGC, DST, CCRUM and MPCST. She has published more than 100 research papers. 